\title{
Correction to: An efficient feature subset selection approach for machine learning
}

\section{Thomas Rincy $\mathbf{N}^{1} \cdot$ Roopam Gupta ${ }^{2}$}

Published online: 13 December 2021

○) Springer Science+Business Media, LLC, part of Springer Nature 2021

\section{Correction to: Multimedia Tools and Applications (2021) 80:12737-12830 https://doi.org/10.1007/s11042-020-10011-7}

In the fifth line of the first paragraph of section 2.1.1 The problem, the word "relevant" was misspelled as "irrelevant." The original article has been corrected.

Publisher's note Springer Nature remains neutral with regard to jurisdictional claims in published maps and institutional affiliations.

The online version of the original article can be found at https://doi.org/10.1007/s11042-020-10011-7

Thomas Rincy N

rinc_thomas@rediffmail.com

Roopam Gupta

roopamgupta@rgtu.net

1 Department of Computer Science and Engineering, University Institute of Technology, Rajiv Gandhi Proudyogiki Vishwavidyalaya, Bhopal, M.P, India

2 Department of Information Technology, University Institute of Technology, Rajiv Gandhi Proudyogiki Vishwavidyalaya, Bhopal, M.P, India 